\title{
Treatment of gonorrhoea contracted in the Western Pacific Region
}

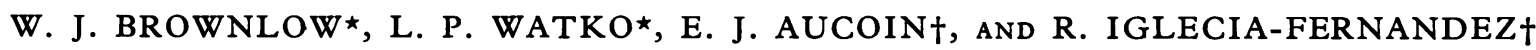 \\ From the ${ }^{*}$ Navy Environmental and Preventive Medicine Unit 6, Pearl Harbour, Hawaii, U.S.A., and the \\ †Medical Department, U.S.S. Oriskany
}

The treatment of acute gonorrhoea continues to be a subject of interest to the medical profession despite the long experience with the disease universally accumulated by physicians. Penicillin is generally accepted to be the drug of choice in its treatment, but other drugs are also effective (Brit. med. F., 1971; Neumann and Baecker, 1972). The evaluation of drug regimens for gonorrhoea is complicated by the ease of re-infection and the shortness of the incubation period. The confounding of treatment failure with re-infection is resolved in military populations isolated by deployment at sea. Holmes, Johnson, and Floyd (1967) reported that patients contracting the disease in the Philippine Islands and treated in 1966 with 2.4 m.u. procaine penicillin $G$ supplemented with probenecid experienced only a 2 per cent. failure rate; these observations were confirmed by additional shipboard studies in the same and subsequent year (Holmes and others, 1968). Patients contracting gonorrhoea in 1968 and 1969 in the same geographical area and treated with the same drug regimen (Keys, Halverson, and Clarke, 1969) also demonstrated a failure rate of 2 per cent. A failure rate of 7.6 per cent. with this regimen was reported by Maurer and Schneider (1969) in patients contracting the disease in Vietnam; however, these patients were not isolated by deployment at sea. Our experience with the treatment of gonorrhoea contracted during 1971 by men embarked upon an aircraft carrier operating in the Gulf of Tonkin is reported in this paper.

\footnotetext{
Received for publication July 17, 1973

Current assignments:

Dr. Brownlow, Navy Environmental and Preventive Medicine Unit 2, Norfolk, Virginia, U.S.A.

Dr. Aucoin, U.S. Naval Hospital, San Diego, Calif., U.S.A.

Dr. Iglecia Fernandez, U.S. Naval Hospital, Bethesda, Md, U.S.A.

The opinions and assertions herein are those of the authors, and are not to be construed as those of the Navy Department or the Naval Service at large.

Address for reprints: Dr. Bıownlow, Navy Environmental and Preventive Medicine Unit 2, Norfolk, Virginia 23511, U.S.A.
}

\section{Material and methods}

The majority of the infections were contracted in the environs of Olongopo City, Republic of the Philippine Islands; nine cases were contracted in Hong Kong. The patients comprised men from an aircraft carrier with a complement of approximately 3,200 which was operating in a combat zone in the Gulf of Tonkin from June to December, 1971. Gonorrhoea was contracted during short periods in port; treatment and follow-up observations were completed while at sea. During the first 3 months of the cruise, patients were treated according to a randomized schedule with one of three drug regimens:

(1) 2.4 m.u. procaine penicillin G intramuscularly, and 1 g. probenecid orally followed by three additional doses of $0.5 \mathrm{~g}$. at 6 -hrly intervals;

(2) 2 g. cephaloridine intramuscularly, and probenecid in the above dosage;

(3) 5 g. cephalexin orally.

During a subsequent period patients were treated consecutively with $2 \mathrm{~g}$. spectinomycin intramuscularly.

Patients who contracted gonorrhoea during periods excluded from either of these two programmes were treated with 2.4 m.u. procaine penicillin G supplemented with probenecid given as above or just a single dose of $1 \mathrm{~g}$.

The patients were instructed to return to the sickbay $2 \mathrm{hrs}$ after treatment was started to have blood samples taken. A serological test for syphilis was performed on each specimen and an aliquot was retained for subsequent bioassay of antibiotic concentration.

Follow-up observations on each patient were scheduled for 5,14 , and 21 days after treatment; the urine was examined and a urethral culture for Neisseria gonorrhoeae was obtained each time the patient returned for assessment. It was not possible to adhere strictly to this schedule for every patient because of the operational commitments of the ship in the combat zone and liberty granted after periods in action, but all had at least one follow-up test and the majority more than one.

Patients treated with penicillin, cephalexin, or cephaloridine were observed for an average of 2 weeks; those given spectinomycin were observed for an average of 3 weeks. Post-gonococcal urethritis was diagnosed on the 
basis of pyuria (20 leucocytes or more per high dry field of wet urinary sediment) and symptoms of urethritis, after the exclusion of $N$. gonorrhoeae by examination of Gramstained smears and by urethral culture.

\section{LABORATORY PROCEDURE}

Each patient reporting to sick call with acute urethritis was asked to cleanse the glans penis with phisohex solution, and to rinse and dry the area. A urethral scraping was obtained by inserting a sterile platinum loop into the distal urethra and withdrawing with gentle pressure. A urine specimen was obtained from the first portion of the urinary stream. Portions of the urinary sediment after centrifugation and the urethral scrapings were cultured for $N$. gonorrhoeae on GC base medium enriched with haemoglobin, and containing 1 per cent. Isovitalex and 1 per cent. VCN inhibitor (Baltimore Biological Laboratories). Isolates were tested aboard ship for oxidase activity. Although Gram-stained smears were examined initially, only those who yielded oxidase-positive colonies on culture were diagnosed and treated as cases of gonorrhoea.

Presumptive cultures of $N$. gonorrhoeae were suspended in trypticase soy broth containing 30 per cent. agammaglobulin horse serum and stored at $-70^{\circ} \mathrm{C}$. aboard ship until they could be transferred in the frozen state to the laboratory at the Navy Environmental and Preventive Medicine Unit 6, Pearl Harbour, Hawaii, for species confirmation by carbohydrate fermentation reactions. Viable cultures were recovered from 217 (47.9 per cent.) of the patients and their identity was confirmed by this method. Sera were also stored at $-70^{\circ} \mathrm{C}$. until bioassays for antibiotic concentrations were performed at this laboratory; bioassays were made by plate-dilution techniques.

\section{Results}

453 men who contracted gonorrhoea during 1971 in the Western Pacific Area were treated with the drug regimens described in Table $I$.

An overall therapeutic success rate of $97 \cdot 6$ per cent. was achieved in the patients treated with 2.4 m.u. procaine penicillin $G$ supplemented with probenecid.
Treatment with $2 \mathrm{~g}$. of cephaloridine supplemented with probenecid was successful in 92.3 per cent. of the cases. Initially probenecid was given with the cephalexin treatment, but it was discontinued because it seemed to increase the amount of nausea and vomiting reported by the first few patients. The therapeutic success rate of patients treated on this single dose regimen of cephalexin without probenecid was 50 per cent.

Spectinomycin (2 g. intramuscularly) was used exclusively for the primary treatment of gonorrhoea after it was received aboard ship until the supply was exhausted. Only 1.6 per cent. of patients so treated failed to respond to this dose of spectinomycin.

All those who failed to respond to the initial regimens of cephalexin, cephaloridine, and spectinomycin were re-treated successfully with $2.4 \mathrm{~m}$.u. procaine penicillin $G$ supplemented with probenecid, with the exception of one who required $4.8 \mathrm{~m}$.u. procaine penicillin plus probenecid. Patients who failed to respond to 2.4 m.u. procaine penicillin plus probenecid were successfully re-treated with $4 \cdot 8 \mathrm{~m}$.u. procaine penicillin plus probenecid.

The average serum concentrations of antibiotics $2 \mathrm{hrs}$ after treatment are presented in Table II.

TABLE II Antibiotic concentrations in sera of patients 2 hours after treatment

\begin{tabular}{|c|c|c|c|}
\hline Antibiotic & $\begin{array}{l}\text { No. of } \\
\text { patients }\end{array}$ & $\begin{array}{l}\text { Mean serum } \\
\text { concentration } \\
(\mu \mathrm{g} . / \mathrm{ml} .)\end{array}$ & $\begin{array}{l}\text { Standard deviation } \\
(\mu \mathrm{g} . / \mathrm{ml} .)\end{array}$ \\
\hline $\begin{array}{l}\text { Penicillin } \\
\text { Cephaloridine } \\
\text { Cephalexin } \\
\text { Spectinomycin }\end{array}$ & $\begin{array}{r}84 \\
42 \\
34 \\
153\end{array}$ & $\begin{array}{r}4 \cdot 2 \\
28 \cdot 4 \\
48 \cdot 9 \\
88 \cdot 6\end{array}$ & $\begin{array}{r}2 \cdot 4 \\
10 \cdot 2 \\
30 \cdot 0 \\
33.9\end{array}$ \\
\hline
\end{tabular}

Circumstances aboard ship precluded serial venepuncture of these patients, and aliquots of sera for antibiotic assay were not available for all those treated during the cruise. Fifteen patients successfully

TABLE I Therapeutic success rates in the treatment of acute gonococcal urethritis contracted in the Western Pacific during 1971

\begin{tabular}{|c|c|c|c|c|}
\hline \multirow{2}{*}{ Month } & \multirow{2}{*}{ Drug regimen } & \multicolumn{3}{|c|}{ No. of cases } \\
\hline & & Total & Cures & Failures \\
\hline June, July, August & $\begin{array}{l}\text { (1) Procaine penicillin } 2.4 \mathrm{~m} . \mathrm{u} \text {. intramuscularly, plus } \\
\text { probenecid } 1 \mathrm{~g} \text {. and } 0.5 \mathrm{~g} \text {. } 6 \text {-hrly for three doses } \\
\text { (2) Cephaloridine } 2 \mathrm{~g} \text {. intramuscularly, plus probenecid } \\
1 \mathrm{~g} \text {. and } 0.5 \mathrm{~g} \text {. } 6 \text {-hrly for three doses } \\
\text { (3) Cephalexin } 5 \mathrm{~g} \text {. orally }\end{array}$ & $\begin{array}{l}68 \\
52 \\
52\end{array}$ & $\begin{array}{l}65 \\
48 \\
26\end{array}$ & $\begin{array}{r}3 \\
4 \\
26\end{array}$ \\
\hline September & $\begin{array}{l}\text { (4) Procaine penicillin } 2.4 \mathrm{~m} . \mathrm{u} \text {. intramuscularly, plus } \\
\text { probenecid } 1 \mathrm{~g} \text {. and } 0.5 \mathrm{~g} .6 \text {-hrly for three doses }\end{array}$ & 64 & 63 & 1 \\
\hline October & (5) Spectinomycin 2 g. intramuscularly & 183 & 180 & 3 \\
\hline November, December & $\begin{array}{l}\text { (6) Procaine penicillin } 2.4 \mathrm{~m} . \mathrm{u} \text {. intramuscularly, plus } \\
\text { probenecid } 1 \mathrm{~g} . \mathrm{stat}\end{array}$ & 34 & 34 & 0 \\
\hline
\end{tabular}


treated with cephalexin had a mean 2-hr blood level of $51 \mu \mathrm{g} . / \mathrm{ml}$. (standard deviation $=35 \cdot 6$ ), whereas the same determination in nineteen patients failing treatment with cephalexin was $49 \mu \mathrm{g} . / \mathrm{ml}$. (standard deviation $=22 \cdot 1$ ). Similarly, in patients treated with penicillin, cephaloridine, or spectinomycin, there were no significant differences in the average blood levels of these antibiotics between the few therapeutic failures and those treated successfully.

The incidence and average time of onset of postgonococcal urethritis in the different treatment groups is shown in Table III. Post-gonococcal urethritis was looked for at each follow-up examination, the earliest investigations being made 5 days after treatment. The onset of this condition in patients treated with penicillin or a cephalosporin tended to occur earlier than in those treated with spectinomycin. However, a significantly smaller number of patients treated with spectinomycin developed it than of those treated with the other antibiotics $(P<\cdot 01)$.

\section{Discussion}

The United States Public Health Service (1972) has recommended that males as well as females be treated with $4.8 \mathrm{~m}$.u. procaine penicillin plus probenecid in order to reduce the therapeutic failures attributed to infections refractory to this drug. Table IV shows the results of treating certain groups of patients in $1966,1967,1968$, and 1971 with 2.4 m.u. procaine penicillin $G$ supplemented with probenecid. In each of the studies summarized in this Table, the population studied was a transient group of naval personnel who contracted gonorrhoea in the Western Pacific Area, primarily the Philippine Islands; the patients from 1966 and 1971 were isolated by deployment at sea during treatment. The sensitivities of our isolates to penicillin and cephaloridine (Watko, 1973) were similar to those reported by Keys and others (1969). No loss of therapeutic effectiveness of this drug regimen occurred between 1966 and 1971 in these groups of patients. A major difference between these populations and those in which the therapeutic effectiveness of drug regimens are usually evaluated is the lack of the necessity to rely upon the veracity of the patient and the expertise of the interviewer in eliciting a history of sexual re-exposure in order to distinguish true treatment failure from re-infection.

The usefulness of probenecid in increasing and prolonging the blood levels of penicillin has been established (Holmes and others, 1967). While it is commonly recommended that the initial dose of probenecid be given 30 to 60 minutes before the antibiotic, this procedure was impracticable under the conditions existing during our study. Nor was it practicable to require patients in a combat zone to report to sickbay for their subsequent doses of probenecid during the next 18 hours. Since there was no assurance that each patient was taking all the probenecid as prescribed, it was decided late in the cruise to give only $1 \mathrm{~g}$. probenecid at the same time as the penicillin. The effectiveness of treatment was not affected by these different procedures involving the probenecid, but only a few men received the lower dose.

Our success rate of 92 per cent. with cephaloridine and probenecid is similar to the rate of 84 per cent. reported by Keys and others (1969) in patients given cephaloridine alone. The poor results observed with cephalexin may be attributed to the single-dose regimen of the drug and to the lack of probenecid to prolong its effectiveness. A 30 per cent. failure rate with cephalexin was observed in a small group of patients treated by Taylor and Holloway (1970) with a single dose of $3 \mathrm{~g}$. Willcox and Woodcock (1970) were able to reduce the failure rate with cephalexin to about 13 per cent. either by supplementing it with probenecid or by giving two doses of $2 \mathrm{~g}$. cephalexin at an interval of $5 \mathrm{hrs}$.

These results further demonstrate that spectino-

TABLE IV Comparison of the 1966-1968 and 1971 therapeutic success rates of $2.4 \mathrm{~m} . u$. procaine penicillin intramuscularly plus probenecid in the treatment of acute gonococcal urethritis

\begin{tabular}{|c|c|c|c|c|c|c|}
\hline \multirow{2}{*}{$\begin{array}{l}\text { Year } \\
\text { contracted }\end{array}$} & \multicolumn{2}{|c|}{ Cures } & \multicolumn{2}{|c|}{ Failures } & \multicolumn{2}{|c|}{ Total } \\
\hline & No. & Per cent. & No. & Per cent. & No. & Per cent. \\
\hline $\begin{array}{l}1966-1968^{\mathrm{a}} \\
1971\end{array}$ & $\begin{array}{l}158 \\
162\end{array}$ & $\begin{array}{l}98 \cdot 1 \\
97 \cdot 6\end{array}$ & $\begin{array}{l}3 \\
4\end{array}$ & $\begin{array}{l}1 \cdot 9 \\
2 \cdot 4\end{array}$ & $\begin{array}{l}161 \\
166\end{array}$ & $\begin{array}{l}100 \\
100\end{array}$ \\
\hline
\end{tabular}

aCombined data of Holmes, Johnson, and Floyd (1967), and Keys, Halverson, and Clarke (1969).

TABLE III Incidence of post-gonococcal urethritis (PGU) among patients given various treatment regimens

\begin{tabular}{|c|c|c|c|c|c|}
\hline \multirow{2}{*}{ Treatment } & \multirow{2}{*}{ Total patients } & \multicolumn{2}{|l|}{ Average no. of days } & \multicolumn{2}{|c|}{ Post-gonococcal urethritis } \\
\hline & & Patients observed & PGU onset & No. & Per cent. \\
\hline $\begin{array}{l}\text { Penicillin } \\
\text { Cephaloridine } \\
\text { Cephalexin } \\
\text { Spectinomycin }\end{array}$ & $\begin{array}{r}64 \\
48 \\
26 \\
180\end{array}$ & $\begin{array}{l}17 \\
15 \\
15 \\
21\end{array}$ & $\begin{array}{l}11 \\
10 \\
11 \\
14\end{array}$ & $\begin{array}{r}21 \\
13 \\
8 \\
20\end{array}$ & $\begin{array}{l}32 \cdot 8 \\
27 \cdot 1 \\
30 \cdot 8 \\
11 \cdot 1\end{array}$ \\
\hline
\end{tabular}


mycin is highly effective in the treatment of gonorrhoea contracted in the Western Pacific Region (Hafermann, Cooper, and Chesney, 1973; Platts, 1970), and they supplement similar observations on the treatment of gonorrhoea contracted in other parts of the world (Tiedemann, Hackney, and Price, 1965; Pedersen, Wiesner, Holmes, Johnson, and Turck, 1972; Reyn, Schmidt, Trier, and Bentzon, 1973; Stratigos, Marsellou-Kinti, Kassimatis, and Daikos, 1973). The low incidence of post-gonococcal urethritis associated with the use of spectinomycin in this study, and the incidence of 5.5 per cent. reported by Hafermann and others (1973) in patients contracting gonorrhoea in Thailand and the Philippines suggests that this may be an additional benefit derived from the treatment of gonorrhoea with spectinomycin. It should be noted that earlier reports of its use in the treatment of non-gonococcal urethritis were considerably less favourable (Willcox, 1963; Csonka, 1971). The treatment of gonorrhoea with spectinomycin has been criticized because it has not been demonstrated to be effective in the treatment of syphilis, and because it may suppress the clinical symptoms of syphilis contracted simultaneously with gonorrhoea (Pedersen and others, 1972; Clark and Yobs, 1964). This problem can be circumvented by the use of serial serological tests for syphilis when spectinomycin is used to treat gonorrhoea. In military populations the patients are accessible for serological evaluation at appropriate intervals after exposure to risk of venereal infection; the serological surveillance of civilian patients is frequently more difficult.

\section{Summary}

453 men with acute gonococcal urethritis were treated with regimens of four antibiotics while deployed at sea during 1971. Among 166 patients treated with 2.4 m.u. procaine penicillin $G$ supplemented with probenecid, the failure rate was only 2.5 per cent. A failure rate of 1.6 per cent. was observed in 183 men treated with $2 \mathrm{~g}$. spectinomycin compared with $7 \cdot 7$ per cent. in 52 men who received $2 \mathrm{~g}$. cephaloridine plus probenecid and 50 per cent. in another 52 men who received $5 \mathrm{~g}$. cephalexin in one dose.

Post-gonococcal urethritis occurred in approximately 30 per cent. of those treated with penicillin or cephalosporins, but in only 11 per cent. of those treated with spectinomycin.

This work could not have been undertaken without the enthusiastic support of the medical department by Capt. Frank S. Haak, Commanding Officer, USS Oriskany. Cephaloridine (Loridine) and cephalexin (Keflex) were provided through the courtesy of the Eli Lilly Company; spectinomycin (Trobicin) was provided through the courtesy of the UpJohn Company.

\section{References}

Brit. med. F. (1972) Editorial, 2, 421

Clark, J. W., and YoBs, A. R. (1964) Brit. F. vener. Dis., 40, 53

Csonka, G. (1971) Postgrad. med. F., 47, Suppl. (Feb.), p. 122

Hafermann, D. R., Cooper, T. S., and Chesney, M. A. (1973) Milit. Med., 138, 14

Holmes, K. K., Johnson, D. W., and Floyd, T. M. (1967) F. Amer. med. Ass., 202, 461

- - - S Stewart, S., and Kvale, P. A. (1968) Milit. Med., 133, 642

Keys, T. F., Halverson, C. W., and Clarke, E. J. (1969) f. Amer. med. Ass., 210, 857

MAURER, L. H., and SCHNEIDER, T. J. (1969) Ibid., 207, 946

Neumann, H. H., and Baecker, J. M. (1972) Ibid., 219, 471

Pedersen, A. H. B., Wiesner, P. J., Holmes, K. K., Johnson, C. J., and TuRCK, M. (1972) Ibid., 220, 205

Platts, W. M. (1970) Med.F. Aust., 2, 500

Reyn, A., Schmidt, H., Trier, M., and Bentzon, M. W. (1973) Brit. F. vener. Dis., 49, 54

Stratigos, J. D., Marsellou-Kinti, O., Kassimatis, V., and DAIKos, G. K. (1973) Ibid., 49, 60

Taylor, W. A., and Holloway, W. J. (1970) Delaware med. F., 42, 356

Tiedemann, J. H., Hackney, J. F., and Price, E. V. (1965) F. Amer. med. Ass., 191, 89

Watko, L. P. (1973) Personal communication.

WILlcox, R. R. (1963) Brit. F. vener. Dis., 39, 21

- - and Woodcock, K. S. (1970) Postgrad. med. f., 46, Suppl. (Oct), p. 103

United States Public Health Service (1972) Morb. Mort. Week. Rep., 21, 82

\section{Traitement de la gonococcie contractée dans la région du Pacifique Occidental}

\section{SOMMAIRE}

Quatre types de traitement par les antibiotiques furent administrés à $\mathbf{4 5 3}$ hommes atteints d'urétrite gonococcique aigüe alors qu'ils étaient en mer, au cours de 1971 . Pour 116 malades traités par 2,4 m.u. de pénicilline G-procaïne, complétée par le probénécide, le taux d'échec fut seulement de 2,5 pour cent. Un taux d'échec de 1,6 pour cent fut observé chez 183 hommes traités par $2 \mathrm{~g}$ de spectinomycine en comparaison avec 7,7 pour cent chez 52 hommes recevant $2 \mathrm{~g}$ de céphaloridine plus probénécide et de 50 pour cent chez 52 autres hommes recevant $5 \mathrm{~g}$ de céphaloxine en une seule dose.

L'urétrite post-gonococcique survint chez à peu près 30 pour cent des sujets traités par la pénicilline ou les céphalosporines, mais seulement chez 11 pour cent de ceux traités avec la spectinomycine. 